\title{
Konstitusionalitas Pengaturan Dekonsentrasi Dalam Undang-Undang Nomor 23 Tahun 2014 tentang Pemerintahan Daerah
}

\author{
William Sanjaya*
}

\begin{abstract}
Abstrak
Dekonsentrasi adalah salah satu mekanisme yang sangat penting dalam penyelenggaraan urusan pemerintah pusat di daerah. Pengaturan mengenai dekonsentrasi ini terdapat dalam UU Nomor 23 Tahun 2014 tentang Pemerintahan Daerah (UU Pemda 2014) yang belum lama ini menggantikan UU Nomor 32 Tahun 2004 tentang Pemerintahan Daerah (UU Pemda 2004). Salah satu hal menarik dari UU Pemda 2014 adalah mengenai pengaturan dekonsentrasi yang diberlakukan hingga ke daerah kabupaten dan kota, yang pada dasarnya dalam pengaturan UU Pemda 2004, dekonsentrasi sebelumnya hanya diberlakukan kepada daerah provinsi. Sekarang ini kedudukan daerah kabupaten dan kota bukan hanya sebagai daerah otonom yang memiliki kewenangan untuk mengatur sendiri urusan daerahnya, tapi juga sebagai wilayah administratif yang dapat melaksanakan pelimpahan wewenang dari pusat untuk menyelenggarakan urusan pemerintahan absolut. Sementara itu, jika dilihat landasan konstitusionalnya, pada Pasal 18, 18A, dan 18B UUD 1945 justru dekonsentrasi tidaklah diatur. Selain itu, dengan menguatnya kembali pengaturan mengenai dekonsentrasi, UU Pemda 2014 dianggap bercorak sentralistik.
\end{abstract}

Kata Kunci: dekonsentrasi, desentralisasi, konstitusionalitas, sentralisasi, UU Pemda.

\section{Constitutionality of Deconcentration Regulation in Law Number 23 of 2014 Concerning Local Government}

\begin{abstract}
Deconcentration is an important mechanism for the implementation of central government on the regional level. The regulation concerning deconcentration contained in Law Number 23 of 2014 Concerning Local Government (Local Government Law 2014) that has recently amended by Law Number 32 of 2004 Concerning Local Government (Local Government Law 2004). An interesting aspect of the Local Government Law 2014 is the implementation of deconcentration even at the level of regency and town. In the Local Government Law 2004, deconcentration was only implemented at regional level. Today, the position of regency and town is not only as autonomous region with a capacity of managing their own local affairs, but also as administrative unit capable of bestowal of authority from the central government to perform absolute governmental affairs. However, in the Article 18,18A, and 18D of the

PADJADJARAN Jurnal Ilmu Hukum Volume 2 Nomor 3 Tahun 2015 [ISSN 2460-1543] [e-ISSN 2442-9325]

* Makalah ini disusun dalam rangka Simposium Nasional Pemerintahan Daerah dengan Tema "Politik Hukum Pemerintahan Daerah Menurut Undang-Undang Nomor 23 Tahun 2014: Desentrasisasi atau Re-Sentralisasi?" pada 8 Juni 2015 di Fakultas Hukum Universitas Padjadjaran, Bandung.

** Mahasiswa Program Studi Magister Hukum Tata Negara, Fakultas Hukum, Universitas Padjadjaran, Jl. Dipati Ukur No. 35 Bandung, fxwiliamsanjaya@gmail.com, S.H. (Universitas Parahyangan).
\end{abstract}


1945 Constitution which should serve as its constitutional foundation, deconcentration is never actually regulated. Furthermore, the implementation of deconcentration makes the Local Government Law 2014 a more centralistic law in nature.

Keywords: deconcentration, decentralization, constitutionality, centralization, Local Government Law.

\section{A. Pendahuluan}

Sejak dibentuknya negara Indonesia, para founding fathers telah menyadari bahwa negara ini memiliki daerah yang sangat luas, terpisah oleh lautan dan tiap-tiap wilayah memiliki ciri khas, juga keunikan serta potensi yang beragam. Disadari betul bahwa negara ini harus dibentuk menjadi negara kesatuan yang dibagi-bagi atas daerah-daerah yang atas setiap daerahnya diberikan kewenangan untuk mengatur dan mengurus daerahnya sesuai dengan potensi dan kekhasan daerahnya masingmasing. Paradigma ini menjadi latar belakang dibentuknya suatu pemerintahan daerah berdasarkan Pasal 18 Undang-Undang Dasar 1945 (UUD 1945) yang bertujuan untuk mempercepat terwujudnya kesejahteraan masyarakat daerah dengan cara pemerataan pembangunan hingga ke daerah.

Namun, setelah selama ini negara telah merdeka dengan beberapa pengaturan mengenai pemerintahan daerah yang pernah berlaku, mayoritas daerah masih saja tertinggal dan belum merasakan pembangunan dan perkembangan yang signifikan. Tidak heran pada saat dilakukannya amendemen UUD 1945 pada tahun 1999-2002 salah satu agenda utama perubahan UUD 1945 adalah mengenai pemerintahan daerah. Akhirnya pada tahun 2000 saat amendemen kedua dilaksanakan terjadi perubahan pada Pasal 18 UUD 1945 tersebut. Perubahan tersebut dilakukan baik struktur maupun substansi dari Pasal 18 UUD 1945. Perubahan tersebut sangat mendasar, yang semula hanya Pasal 18 UUD 1945 saja menjadi Pasal 18, 18A, dan 18B UUD 1945. Penggantian secara menyeluruh ini pun berakibat kepada penjelasan UUD 1945. Penjelasan yang selama ini ikut menjadi acuan dalam mengatur pemerintahan daerah menjadi tidak berlaku lagi. Dengan demikian, sumber konstitusional dari pemerintahan daerah di Indonesia hanyalah pada Pasal 18, 18A, dan 18B UUD 1945 . $^{1}$

Pengaturan lebih lanjut mengenai pemerintahan daerah sekarang ini adalah melalui Undang-Undang Nomor 23 Tahun 2014 tentang Pemerintahan Daerah (UU Pemda 2014). Berlakunya UU Pemda 2014 yang menggantikan UU Pemda 2004 sebelumnya menghasilkan cukup banyak perubahan. Salah satu perubahan tersebut adalah mengenai dekonsentrasi, yang sebelumnya dalam UU Pemda 2004 dinyatakan sebagai pelimpahan wewenang pemerintahan oleh pemerintah kepada

\footnotetext{
1 Ni'matul Huda, Hukum Pemerintahan Daerah, Bandung: Penerbit Nusa Media, 2009, hlm. 49.
} 
gubernur sebagai wakil pemerintah dan/atau kepada instansi vertikal di wilayah tertentu. ${ }^{2}$ Artinya, dekonsentrasi hanya dilakukan atau diselenggarakan oleh gubernur sebagai wakil pemerintah pusat dan instansi vertikal saja. Sedangkan menurut aturan dalam UU Pemda 2014, pengertian dekonsentrasi adalah pelimpahan wewenang pemerintahan oleh pemerintah kepada gubernur sebagai wakil pemerintah dan/atau kepada instansi vertikal di wilayah tertentu dan/atau kepada gubernur dan bupati/walikota sebagai penanggung jawab urusan pemerintahan umum. ${ }^{3}$ Artinya, pada ketentuan ini diatur bahwa dekonsentrasi bukan hanya dilakukan oleh gubernur sebagai wakil pemerintah pusat dan instansi vertikal saja, tapi bupati atau walikota pun kini dapat menyelenggarakan urusan pemerintah pusat melalui dekonsentrasi. Hal ini juga mengandung makna bahwa kedudukan kabupaten dan kota bukan hanya sebagai daerah otonom melalui desentralisasi, namun juga sebagai wilayah administratif dengan dekonsentrasi. ${ }^{4}$

Menurut Amrah Muslimin yang dikutip oleh Iskatrinah dalam disertasinya, dekonsentrasi sebagai pelimpahan sebagian dari kewenangan pemerintah pusat pada alat-alat pusat yang ada di daerah atau pelaksanaan urusan pemerintah pusat yang tidak diserahkan kepada satuan pemerintahan daerah, yang dilakukan oleh organ pemerintahan pusat yang ada di daerah. Pada hakikatnya, alat pemerintah pusat ini melaksanakan pemerintahan sendiri di daerah dan berwenang mengambil keputusan sendiri sampai tingkat tertentu berdasarkan tanggung jawab kepada pemerintah pusat, sebagai pemikul biaya dan tanggung jawab terakhir mengenai urusan dekonsentrasi. ${ }^{5}$ Melalui dekonsentrasi, terbentuklah wilayah administratif. Juniarto menyebutnya dengan istilah pemerintahan lokal-administratif. Pemerintahan lokal-administratif dengan daerah administratif dibentuk karena penyelenggaraan segala urusan-urusan pemerintahan pusat yang berkedudukan di ibukota negara tidak akan dapat dilaksanakan seluruhnya sendiri oleh pemerintah pusat. $^{6}$

Pada perkembangannya, kewenangan dalam penyelenggaraan dekonsentrasi mengalami pasang surut dalam perubahan struktur pemerintahan di Indonesia. Sejalan dengan kebutuhan kebangsaan, perubahan struktur pemerintahan melalui peraturan perundang-undangan yang ada telah mengalami delapan kali perubahan sejak kemerdekaan. Pada dasarnya, kebijakan dekonsentrasi mendapat perhatian

2 Pasal 1 angka 8 UU Pemda 2004.

3 Pasal 1 angka 9 UU Pemda 2014.

4 Pasal 1 angka 13 UU Pemda 2014, "Wilayah Administratif adalah wilayah kerja perangkat Pemerintah Pusat termasuk Gubernur sebagai wakil Pemerintah Pusat untuk menyelenggarakan Urusan Pemerintahan yang menjadi kewenangan Pemerintah Pusat di Daerah dan wilayah kerja gubernur dan bupati/walikota dalam melaksanakan urusan pemerintahan umum."

5 Iskatrinah, "Dekonsentrasi Dalam Penyelenggaraan Otonomi Luas Berdasarkan Undang-Undang Dasar 1945", Disertasi Fakultas Hukum Universitas Padjadjaran, 2015, hlm. 1.

6 Ibid. 
pada perubahan di tahun 1945 dan 1965. Sedangkan perubahan yang menyeimbangkan antara desentralisasi dan dekonsentrasi dilakukan sebanyak tiga kali, yakni tahun 1957, 1974, dan tahun 2004. Terakhir, dengan berlakunya UU Pemda 2014, pengaturan dalam UU tersebut juga menggabungkan kebijakan desentralisasi, dekonsentrasi, dan tugas pembantuan. Selengkapnya perubahan kebijakan tersebut dapat diperhatikan sebagai berikut: ${ }^{7}$

1. Undang-Undang Nomor 1 Tahun 1945 tentang Otonomi Daerah lebih menitikberatkan pada kebijakan dekonsentrasi;

2. Undang-Undang Nomor 22 Tahun 1948 tentang Pemerintahan Daerah lebih menitikberatkan pada kebijakan desentralisasi;

3. Undang-Undang Nomor 1 Tahun 1957 tentang Pokok-Pokok Pemerintahan Daerah menggabungkan desentralisasi dan dekonsentrasi ;

4. Peraturan Presiden Nomor 6 Tahun 1959 tentang Penyerahan Tugas-Tugas Pemerintah Pusat Dalam Bidang Pemerintahan Umum, Perbantuan Pegawai Negeri, dan penyerahan Keuangannya Kepada Pemerintahan Daerah menitikberatkan pada kebijakan dekonsentrasi;

5. Undang-Undang Nomor 18 Tahun 1965 tentang Pokok-Pokok Pemerintahan Daerah menitikberatkan pada kebijakan desentralisasi;

6. Undang-Undang Nomor 5 Tahun 1974 tentang Pokok-Pokok Pemerintahan di Daerah menggabungkan kebijakan desentralisasi, dekonsentrasi, dan tugas pembantuan;

7. Undang-Undang Nomor 22 Tahun 1999 tentang Pemerintahan Daerah menitikberatkan pada kebijakan desentralisasi;

8. UU Pemda 2004 menggabungkan kebijakan desentralisasi, dekonsentrasi, dan tugas pembantuan; dan

9. UU Pemda 2014 menggabungkan kebijakan desentralisasi, dekonsentrasi, dan tugas pembantuan.

Isu menarik mengenai dekonsentrasi adalah seringnya dekonsentrasi dipertentangkan dengan desentralisasi, dalam artian dengan adanya dekonsentrasi ini akan mengancam desentralisasi serta dinilai seolah-olah kembali menjadi sentralisasi. Padahal dekonsentrasi dimaksudkan sebagai cara untuk menjaga dan mempertahankan keutuhan negara kesatuan. Akan tetapi, dengan semangat otonomi luas sering ditafsirkan bahwa dekonsentrasi akan memandulkan otonomi. Dalam catatan Abdurahman yang dikutip oleh Iskatrinah, ${ }^{8}$ menyatakan bahwa:

“... di satu pihak, pemerintah melaksanakan suatu bentuk otonomi yang tidak membahayakan kedudukan pemerintah pusat sebagai pemegang

\footnotetext{
7 TIM PKP2A III LAN, “Kewenangan Dekonsentrasi Dalam Penyelenggaraan Otonomi Daerah dan Permasalahan Penyelenggaraannya di Daerah", Penelitian PKP2A III LAN Samarinda, 2007, hlm. 7. Lihat juga Iskatrinah, Op.cit., hlm. 58-59.

8 Ibid.
} 
keputusan dan penanggungjawab dari sistem negara kesatuan, pada pihak lain, dengan mekanisme yang diatur sedemikian rupa diharapkan tidak akan mengekang kebebasan dan perkembangan daerah-daerah dalam kerangka mencapai tujuan nasional."

Pandangan ini pun terjadi pada saat keluarnya UU Pemda 2014 yang didalamnya mengatur perluasan cakupan dekonsentrasi dari yang sebelumnya hanya diberlakukan kepada provinsi yang dipimpin oleh gubernur yang memiliki kedudukan sebagai kepala daerah otonom juga sebagai wakil pemerintah pusat di daerah. Kemudian, diberlakukan juga kepada kabupaten dan kota sebagai penanggung jawab urusan pemerintahan umum. Oleh karena itu, UU Pemda 2014 ini dinilai bercorak sentralistik.

\section{B. Pembahasan}

\section{Makna Konstitusional Pasal 18 UUD 1945}

Untuk memaknai pengaturan pemerintahan daerah, khususnya yang tercantum dalam Pasal 18 UUD 1945, tidak boleh dilepaskan dengan landasannya yaitu bentuk negara kesatuan. Pengaturan mengenai Negara Kesatuan Republik Indonesia (NKRI) di dalam UUD 1945 dapat ditemukan pada sejumlah pasal, antara lain:

a. Pasal 1 ayat (1) UUD 1945: Negara Indonesia ialah Negara Kesatuan, yang berbentuk Republik;

b. Pasal 25A: Negara Kesatuan Republik Indonesia adalah sebuah negara kepulauan yang berciri Nusantara dengan wilayah yang batas-batas dan hakhaknya ditetapkan dengan undang-undang; dan

c. Pasal 37 ayat (5): Khusus mengenai bentuk Negara Kesatuan Republik Indonesia tidak dapat dilakukan perubahan.

Sementara itu, pengaturan mengenai pemerintahan daerah dalam UUD 1945 diatur dalam Pasal 18, 18A, dan 18B UUD 1945.

Dalam konteks bentuk negara, meskipun bangsa Indonesia memilih bentuk negara kesatuan, tetapi di dalamnya terselenggara suatu mekanisme yang memungkinkan tumbuh dan berkembangnya keragaman antar daerah di seluruh tanah air. Kekayaan alam dan budaya antar daerah tidak boleh diseragamkan dalam struktur NKRI. Dengan kata lain, bentuk NKRI diselenggarakan dengan jaminan otonomi yang seluas-luasnya kepada daerah-daerah untuk berkembang sesuai dengan potensi kekayaan yang dimilikinya masing-masing. Tentunya dengan dorongan, dukungan, dan bantuan yang diberikan oleh pemerintah pusat. ${ }^{9}$

Istilah 'dibagi atas' (bukan terdiri atas) dalam ketentuan Pasal 18 ayat (1) UUD 1945 bukanlah istilah yang digunakan secara kebetulan. Istilah itu langsung menjelaskan bahwa negara kita adalah negara kesatuan dimana kedaulatan negara

9 Jimly Asshiddiqie, Konstitusi \& Konstitusionalisme Indonesia, Jakarta: Konstitusi Press, 2005, hlm. 79. 
berada di tangan pusat. Hal ini konsisten dengan kesepakatan untuk tetap mempertahankan bentuk negara kesatuan. Berbeda dengan istilah 'terdiri atas' yang lebih menunjukkan substansi federalisme karena istilah itu menunjukkan letak kedaulatan berada di tangan negara-negara bagian. ${ }^{10}$ Substansi pembagian daerah dalam NKRI yang diatur dalam Pasal 18 ayat (1) UUD 1945 ini dimaksudkan untuk lebih memperjelas pembagian daerah dalam NKRI yang meliputi daerah provinsi dan dalam daerah provinsi terdapat daerah kabupaten dan kota.

Jimly Asshiddiqie menegaskan bahwa ketentuan baru, yakni Pasal 18, 18A, dan 18B UUD 1945 telah mengubah format bentuk negara kita dari bentuk negara kesatuan yang kaku kepada bentuk negara kesatuan yang dinamis. Artinya, pertama, dimungkinkan untuk dilakukannya pengaturan-pengaturan yang bersifat federalistis dalam hubungan antara pemerintah pusat dan pemerintah daerah. Kedua, dalam dinamika hubungan antara pusat dan daerah itu dimungkinkan pula dikembangkannya kebijakan otonomi yang bersifat pluralistis, dalam arti bahwa untuk setiap daerah dapat diterapkan pola otonomi yang berbeda-beda. Keragaman pola hubungan itu telah dibuktikan dengan diterimanya prinsip otonomi khusus Provinsi Nanggroe Aceh Darussalam dan Provinsi Papua, yang keduanya memiliki format kelembagaan pemerintahan yang berbeda dengan pemerintahan daerah lain pada umumnya. ${ }^{11}$

Pada Pasal 18, 18A, dan 18B UUD 1945 tidak diberikan penegasan mengenai dekonsentrasi dalam penyelenggaraan pemerintahan daerah. Misalnya, Pasal 18 ayat (2) perubahan UUD 1945 diatur bahwa pemerintah daerah provinsi, daerah kabupaten dan kota mengatur dan mengurus sendiri urusan pemerintahan menurut asas otonomi dan tugas pembantuan. Di bagian lain disebutkan bahwa pemerintahan daerah menjalankan otonomi seluas-luasnya, kecuali urusan pemerintahan yang oleh undang-undang ditentukan sebagai urusan pemerintah pusat. ${ }^{12}$ Namun dalam praktik, dekonsentrasi tetap ada di daerah.

Menurut Jimly Asshiddiqie, seharusnya dalam Pasal 18 ayat (2) UUD 1945 tersebut dimuat pula mengenai asas dekonsentrasi, bukan hanya asas otonomi dan tugas pembantuan. Bahkan dalam sistem federal sekalipun, seperti di Amerika dan Australia, asas-asas pemerintahan daerah itu selalu mencakup tiga asas, yakni desentralisasi (otonomi), dekonsentrasi, dan tugas pembantuan. ${ }^{13}$ Sebaliknya, menurut Bhenyamin Hoessein yang dikutip oleh Ni'matul Huda justru berbeda pendapat. Menurutnya, Pasal 18 ayat (2) ini secara salah menyebut otonomi sebagai asas. Walaupun demikian, pada ayat ini diisyaratkan hanya dianutnya

\footnotetext{
10 Majelis Permusyawaratan Rakyat RI, Panduan Dalam Memasyarakatkan UUD Negara Republik Indonesia Tahun 1945, Jakarta: Sekretariat Jendral MPR RI, 2003, hlm.23.

11 Jimly Asshiddiqie, Op.cit., hlm.275.

12 Pasal 18 ayat (5) UUD 1945.

13 Jimly Asshiddiqie, Op.cit., hlm. 274.
} 
desentralisasi (otonomi) dan tugas pembantuan. Asas dekonsentrasi tidak disebut ataupun diatur dalam UUD 1945. Sikap demikian sangat bijaksana, karena dekonsentrasi sebagai penghalusan dari sentralisasi. Asas sentralisasi mutlak dianut dalam organisasi negara. Disamping itu, asas dekonsentrasi memang hampir tidak pernah diatur dalam konstitusi khususnya Fragmented Field Administration Sistem. ${ }^{14}$

Senada dengan pendapat tersebut, menurut Bagir Manan dalam pengertian umum, desentralisasi adalah setiap bentuk atau tindakan memencarkan kekuasaan atau wewenang dari suatu organisasi, jabatan, atau pejabat. Dengan demikian, dekonsentrasi dalam pengertian umum dapat juga dipandang sebagai suatu bentuk desentralisasi, karena mengandung makna pemencaran kekuasaan. ${ }^{15}$ Van der Pot menggambarkan desentralisasi dengan menyebutkan bahwa tidak semua peraturan penyelenggaraan pemerintahan dilakukan dari pusat (sentral). Pelaksanaan pemerintahan dilakukan baik oleh pusat maupun berbagai badan otonom. Badan-badan otonom ini dibedakan antara desentralisasi berdasarkan territorial (territorial decentralisatie) dan desentralisasi fungsional (functioneele decentralisatie). Bentuk desentralisasi itu menurut Van der Pot dapat dibedakan antara otonomi dan tugas pembantuan. ${ }^{16}$

Desentralisasi tidak sama dengan otonomi. Desentralisasi bukan asas melainkan suatu proses. Hal yang merupakan asas adalah otonomi dan tugas pembantuan. Dekonsentrasi bukan asas tetapi proses atau cara menyelenggarakan sesuatu. Dekonsentrasi adalah subsistem sentralisasi yaitu cara menyelenggarakan sistem sentralisasi. Karena itu, sangat keliru kalau ditempatkan dalam sistematik pemerintahan daerah yang merupakan antitesis dari sentralisasi. ${ }^{17}$

\section{Dekonsentrasi Dalam Sistem Pemerintahan Daerah}

Indonesia merupakan negara kesatuan, yaitu negara yang kekuasaan negaranya ada di tangan pusat, namun memiliki juga suatu pemerintahan daerah yang mendapatkan kekuasaan dari pusat melalui penyerahan sebagian kekuasaan yang ditentukan secara tegas, yang sistem pelaksanaan pemerintahannya dapat dilaksanakan dengan cara/sistem sentralisasi/dekonsentrasi, desentralisasi dan medebewind/tugas pembantuan. Pada sistem sentralisasi/dekonsentrasi, kedaulatan negara baik ke dalam dan ke luar ditangani pemerintah pusat dan dilimpahkan melalui organ-organ pusat yang terdapat di daerah (dekonsentrasi). Namun, karena luasnya daerah-daerah di negara kita yang terbagi-bagi atas beberapa provinsi, kabupaten, dan kota, di samping setiap daerah-daerah memiliki kemajemukan, kekhususan, kekhasan serta potensi yang besar yang tidak dapat

\footnotetext{
14 Ni'matul Huda, Op.cit., hlm. 54.

15 Bagir Manan, Menyongsong Fajar Otonomi Daerah, Yogyakarta: Pusat Studi Hukum FH UII, 2001, hlm. 10.

16 Ibid.

17 Ibid., hlm. 11.
} 
hanya diatur atau diurus oleh pemerintah pusat saja. Daerah-daerah tersebut memiliki pemerintahan daerah melalui desentralisasi atau penyerahan wewenang dari pusat dengan maksud untuk mengatur dan mengurus urusan pemerintahannya sendiri sesuai dengan kekhususan dan potensi daerahnya tersebut demi menyejahterakan rakyat di daerahnya.

Pada praktiknya, desentralisasi yang dimaknai sebagai 'penyerahan' sebagian wewenang memang telah tumpang tindih dengan tugas dan wewenang pusat dalam bentuk dekonsentrasi atau 'pelimpahan' sebagian wewenang dari pusat kepada pemerintah daerah (khususnya kabupaten/kota) dan juga tugas pembantuan. Penguatan peran pemerintah pusat dengan dekonsentrasi memang secara implisit bukan sekedar menambah peran yang sebelumnya mengecil, melainkan lebih jauh dilandasi oleh pemikiran ke depan yakni menjaga kedulatan suatu negara bangsa (nation-state). Untuk itu, perundangan tersebut memberikan landasan bahwa pemerintah pusat berhak melakukan intervensi dalam bentuk supervisi, pembinaan, pengawasan, dan penilaian kinerja otonomi pada pemerintahan daerah. Hak Pemerintahan Pusat dijalankan secara langsung oleh instansi tingkat pusat (Lembaga Pemerintahan Non Departemen (LPND)), maupun secara tidak langsung dengan pelimpahan wewenang melalui aparatnya yang ada di daerah, yaitu gubernur. ${ }^{18}$ Artinya, posisi pemerintah provinsi dalam koridor otonomi daerah memiliki dua kedudukan, yakni sebagai wakil pemerintah pusat dengan menjadikan aparat dekonsentrasi dan menjadi pelaksana otonomi daerah itu sendiri (aparat desentralisasi). Begitupun kabupaten dan kota diposisikan sekarang ini memiliki double function seperti provinsi, yaitu sebagai pelaksana otonomi daerah serta sebagai aparat dekonsentrasi.

Pengkategorian desentralisasi yang banyak dirujuk oleh para ahli sebagaimana dikemukakan oleh Cheema dan Rondinelli serta dikutip oleh TIM PKP2A III LAN, dapat dibedakan menjadi empat kategori, yakni : 1) Delegation to semi autonomous or parastatal organization; 2) Devolution; 3) Transfer of function from government to non-government institution; dan 4) Deconcentration. ${ }^{19}$ Kategori pemaknaan desentralisasi keempat adalah deconcentration (dekonsentrasi). Dekonsentrasi dimaknai sebagai proses re-distribusi tanggung jawab yang bersifat administratif untuk diberikan kepada institusi yang berada dalam sayap pemerintah pusat. Institusi tersebut diwujudkan dengan cara pembentukan dan pengoperasionalan berbagai kantor atau institusi pusat yang ditempatkan di berbagai wilayah atau lembaga pemerintah lain yang berada dibawahnya yang diatur dan ditetapkan melalui perundangan. ${ }^{20}$ Menurut Bernard Bizet:

\footnotetext{
18 Tim PKP2A III LAN, Op.cit., hlm. 2.

19 Ibid., hlm. 4.

20 Ibid., hlm. 4-5.
} 
"Déconcentration whereby centrally located authorities and entities are relocated to government structures in the provinces, physically 'deconcentrating' the center. ${ }^{21}$ Deconcentration was said to be the complement of decentralisation, in order to allow the government to be more sensitive regarding the local level when making decisions within its sphere of power $22 . .$. one of the first advantages of deconcentration is to organise combined action between State authorities and local authorities. Deconcentration organises the separation of powers at the local levels according to each sphere of intervention. Thus, the Prefect can act as a mediator between the local interest and the central policy of national interest."

Disamping itu, Elizabeth Linda Yuliani mengumpulkan beberapa pendapat mengenai dekonsentrasi yang menyatakan bahwa, "Deconcentration, is the term referring to: ${ }^{24}$

a. The process by which the agents of central government control are relocated and geographically dispersed (Sayer et. al.);

b. Administrative decentralization, i.e. a transfer to lower-level central government authorities, or to other local authorities who are upwardly accountable to the central government (Ribot 2002 in Larson);

c. The transfer of administrative responsibility for specified functions to lower levels within the central government bureaucracy, generally on some spatial basis (Ferguson and Chandrasekharan); and

d. One of administrative decentralization which redistributes decisionmaking authority and financial and management responsibility among levels of the central government; there is no real transfer of authority between levels of government. It may involve only a shift of responsibilities from federal forest service officials of the capital city to those stationed in provinces, districts, etc (Gregersen et. al.)."

Keuntungan diterapkannya dekonsentrasi menurut Turner, yang dikutip oleh TIM PKP2A III LAN adalah: ${ }^{25}$

a. Officials are available for consultation, advice, and complaint. As local officials can exercise decentralized authority, they make the

\footnotetext{
21 Bernard Bizet, "Deconcentration versus Decentralization of Administration in France", Canadian Journal of Regional Science, XXV: 3, Autumn, 2002, hlm. 2.

22 Ibid., hlm. 4.

23 Ibid., hlm. 4-5.

${ }^{24}$ Elizabeth Linda Yuliani, “Decentralization, Deconcentration and Devolution: What Do They Mean?”, Interlaken Workshop on Decentralization, Interlaken, Switzerland, 27-30 April 2004, hlm. 3.

${ }^{25}$ TIM PKP2A III LAN, Op.cit., hlm. 6-7.
} 
decisions and do not need to pass them up the line to distant central offices;

b. Mobilization of local resources. It is easier for locally based officials to identify local resources, both human and physical, and then mobilize them in the pursuit of locally determined developmental purposes. Officials should also be familiar with specific local constraints and the dynamics of local politics;

c. Rapid response to local needs. Officials are better placed to respond rapidly to local needs as they are in the territory and fully aware of local conditions;

d. Orientation to the specific local needs. Because officials know the local conditions, they are well placed to make decisions and allocate resources which fit with the specific conditions prevailing in a particular territory. Each sub-national territory may have some unique features which can be taken into account when planningand allocating resources;

e. Motivation of field personnel. Appointed government officials are more motivated to perform well when they have greater responsibility for programs they manage;

f. Inter-office coordination. Coordination between offices dealing with different functions is more easily achieved at the local level where officials are physically close together and are often familiar with each other; and

g. Central agencies. The decentralization of service functions relieves central agencies of routine tasks. Responsibility for these has been passed down to the local level. Central agencies can thus focus on improving the quality of policy. Monitoring local-level performance and providing assistance to sub-national units are key element of this reformulated central government role."

Menurut Jimly Asshiddiqie dalam berbagai literatur hukum, unit pemerintah daerah sebagai organ negara di tingkat daerah-daerah bagian, dikenal ada dua macam bentuk, yaitu pemerintah daerah administratif dan otonom. Pemerintah daerah administratif dibentuk karena pemerintah pusat dipandang tidak dapat menyelenggarakan seluruh urusan pemerintahan negara dari pusat. Untuk itu, dianggap perlu dibentuk unit-unit pemerintahan di daerah yang akan menyelenggarakan segala urusan pusat di daerah. Unit pemerintah daerah itu berfungsi sebagai wakil pusat di daerah dengan tugas menyelenggarakan segala urusan pusat di daerah. Unit pemerintah daerah itu berfungsi sebagai wakil pusat di daerah dengan tugas menyelenggarakan pemerintahan di daerah atas perintahperintah atau petunjuk-petunjuk pemerintah pusat. Oleh karena itu, tugas unit 
pemerintahan daerah hanya berfungsi sebagai penyelenggara administratif saja, sehingga unit pemerintah daerah disebut sebagai pemerintah daerah administratif.

Pemerintah daerah administratif ini dipimpin oleh seorang kepala pemerintahan yang berkedudukan sebagai pegawai pemerintah pusat yang ditempatkan di daerah administratif yang bersangkutan dengan dibantu oleh pegawai-pegawai pemerintah pusat lainnya yang ditempatkan di kantor-kantor atau jawatan-jawatan pusat yang ada di daerah. ${ }^{26}$ Dengan kata lain, prinsip yang berlaku dalam sistem pemerintahan daerah administratif adalah asas dekonsentrasi (deconcentration). Sebaliknya, dalam sistem daerah otonom yang berlaku adalah asas desentralisasi (decentralization) yang sudah ada sejak berlakunya Desentralisatie Wet $1903 .^{27}$

Di dalam negara kesatuan tanggung jawab pelaksanaan tugas-tugas pemerintahan pada dasarnya tetap berada di tangan pemerintah pusat. Akan tetapi, karena sistem pemerintahan Indonesia salah satunya menganut asas negara kesatuan yang didesentralisasikan maka ada tugas-tugas tertentu yang diurus sendiri, sehingga menimbulkan hubungan timbal balik yang melahirkan adanya hubungan kewenangan dan pengawasan. ${ }^{28}$ Mengenai hal tersebut, Bagir Manan berpendapat bahwa negara kesatuan merupakan landasan batas dari isi pengertian otonomi. Berdasarkan landasan batas tersebut dikembangkanlah berbagai peraturan (rules) yang mengatur mekanisme yang akan menjelmakan keseimbangan antara tuntutan kesatuan dan tuntutan otonomi. Di sini pulalah letak kemungkinan spanning yang timbul dari kondisi tarik menarik antara kedua kecenderungan tersebut. ${ }^{29}$

Menurut Ni'matul Huda, tarik menarik antara kedua kecenderungan tersebut bukanlah suatu yang perlu dihilangkan. Upaya untuk menghilangkannya tidak akan pernah berhasil karena hal tersebut merupakan sesuatu yang alami. Kehidupan bernegara dan pemerintahan tidak pernah lepas dari kehidupan masyarakat, baik masyarakatnya sendiri maupun masyarakat di luarnya. Negara atau pemerintah yang baik adalah yang berkiprah sesuai dengan dinamika masyarakatnya. Dalam kondisi itulah semestinya dilihat kecenderungan ke arah kesatuan atau otonomi. ${ }^{30}$ Kalau segalanya dikembalikan kepada kepentingan masyarakat dan terwujud suatu pemerintahan yang sehat, tarik menarik tersebut tidak boleh dilihat sebagai spanning, yakni saat yang satu membahayakan yang lain, melainkan suatu bentuk dinamika yang alami yang akan senantiasa ada pada setiap tingkat perkembangan kehidupan bernegara atau pemerintahan. Selain itu, penting untuk menciptakan

\footnotetext{
26 Jimly Asshiddiqie, Pokok-Pokok Hukum Tata Negara Indonesia Pasca Reformasi, Jakarta: PT Bhuana Ilmu Populer, 2007, hlm. 420-421.

27 Ibid., hlm. 421.

28 Ni'matul Huda, Op.cit., hlm. 43.

29 Bagir Manan, Perjalanan Historis Pasal 18 UUD 1945, Jakarta: UNISKA, 1993, hIm. 3.

${ }^{30} \mathrm{Ni}$ 'matul Huda, Loc. cit.
} 
mekanisme yang wajar agar setiap tarikan bukan hanya peringatan (warning) saja, tetapi juga sebagai masukan (feeding) bagi yang lain. ${ }^{31}$ Sekarang ini, negara kesatuan harus diartikan sebagai unitary, yakni negara kesatuan yang tidak menghilangkan keragaman dari unsur-unsur yang menyatu itu. Kesatuan yang di dalamnya terdapat perbedaan-perbedaan. ${ }^{32}$

Berdasarkan pendapat di atas, dapat dikatakan bahwa tarik-menarik mekanisme desentralisasi dan dekonsentrasi ini tidak perlu dihilangkan, tetapi yang harus dilakukan adalah melakukan penyesuaian dengan keadaan dan kebutuhan negara, daerah, serta masyarakat. Artinya, dalam keadaan tertentu, dekonsentrasi dapat diperkuat di samping desentralisasi yang kuat pula, atau sebaliknya. Dekonsentrasi dapat juga diperluas hingga ke daerah kabupaten dan kota, atau sebaliknya dekonsentrasi hanya diberlakukan kepada provinsi saja, seperti dalam UU Pemda 2004.

Dapat pula diartikan bahwa pandangan yang menilai dekonsentrasi sebagai ancaman bagi desentralisasi dan akan mengembalikan negara ini kepada sistem yang sentralistik adalah pandangan yang keliru, karena pada dasarnya dekonsentrasi adalah suatu mekanisme pelengkap/komplemen dari desentralisasi. Keberadaan dekonsentrasi yang bahkan hingga ke kabupaten dan kota ini adalah suatu keniscayaan, melihat kompleksnya urusan-urusan yang harus diselenggarakan bukan hanya di tataran pusat tapi juga urusan-urusan nasional/pusat hingga ke daerah. Selain itu, harus dipahami bahwa ada beberapa urusan-urusan nasional yang sifatnya harus diberlakukan kepada seluruh daerah di Indonesia dengan sama, tanpa menghilangkan urusan-urusan wajib daerah yang kewenangannya diatur dan diurus oleh pemerintah daerah secara penuh. Antara desentralisasi dan dekonsentrasi dalam NKRI ini bagaikan dua sisi mata uang (dengan tugas pembantuan menjadi triangle mechanism) yang satu dengan yang lainnya tidak dapat dipisahkan, tidak saling mengancam atau melemahkan, dan tidak perlu dipertentangkan. Semua itu perlu dilihat sebagai suatu cara atau sekumpulan sub-sistem yang saling melengkapi satu dengan yang lainnya, yang juga membentuk suatu sistem utuh dari penyelenggaraan pemerintahan dalam pemerintahan daerah.

Perluasan pemberlakuan dekonsentrasi hingga ke kabupaten dan kota sebagai penanggung jawab urusan pemerintahan umum seperti dikemukakan dalam Pasal 1 angka 9 UU Pemda 2014 adalah suatu hal yang sangat beralasan. Hal ini karena semakin kompleksnya kebutuhan penyelenggaraan urusan-urusan nasional hingga daerah, pada luasnya wilayah Indonesia, dan ditambah dengan keinginan untuk mempercepat pembangunan hingga ke daerah. Terkadang, dalam keadaan tertentu pemerintah daerah sendiri membutuhkan dukungan dan bantuan dari pemerintah

\footnotetext{
31 Ibid.

32 Adnan Buyung Nasution, Arus Pemikiran Konstitusionalisme, Jakarta: Kata Hasta Pustaka, 2007, hlm. 131.
} 
pusat untuk menyelesaikan beberapa permasalahan yang ada di daerah. Pengaturan ini pun adalah suatu reaksi dari beberapa fenomena perkembangan penyelenggaraan pemerintahan daerah di Indonesia selama beberapa tahun belakangan. Salah satu penyebabnya karena beberapa waktu yang lalu terdapat beberapa kebijakan atau program nasional yang diambil oleh pusat pada saat akan diberlakukan di daerah, dan terdapat pula beberapa daerah yang justru tidak mau melaksanakan kebijakan tersebut. Disamping itu, dengan semakin kuatnya peran pemerintahan daerah, harus semakin kuat pula peran pemerintah pusat dalam melakukan pengawasan. Salah satunya melalui dekonsentrasi agar pemerintah daerah dapat menyelenggarakan dan mengatur urusan-urusan daerah dan masyarakatnya dalam koridor yang tepat dan sejalan dengan kebijakan-kebijakan nasional.

Disamping hal-hal tersebut, sesuai dengan fungsi lain dari dekonsentrasi untuk merekatkan daerah dalam NKRI dan menyelenggarakan urusan nasional/pusat di daerah, terdapat pula tujuan politis dari dekonsentrasi, yang antara lain adalah untuk menyerap kepentingan-kepentingan dan kebutuhan-kebutuhan daerah secara langsung serta memberikan suatu 'image' bahwa pemerintah pusat pun masih memberikan perhatian kepada daerah. Hal-hal seperti ini penting karena beberapa daerah, khususnya daerah yang jauh dan terpencil, terkadang merasa negara/pemerintah pusat sama sekali tidak memperhatikan daerahnya atau bahkan tidak pernah 'hadir' di daerahnya. Hal ini terkadang memunculkan keinginan-keinginan untuk melepaskan diri dari NKRI.

Pengaturan mengenai dekonsentrasi dalam UU Pemda 2014 terdapat pada beberapa pasal, antara lain:

a. Pasal 1 angka 9: Dekonsentrasi adalah pelimpahan sebagian urusan pemerintahan yang menjadi kewenangan pemerintah pusat kepada gubernur sebagai wakil pemerintah pusat, kepada instansi vertikal di wilayah tertentu, dan/atau kepada gubernur dan bupati/walikota sebagai penanggung jawab urusan pemerintahan umum;

b. Pasal 1 angka 10: Instansi Vertikal adalah perangkat kementerian dan/atau lembaga pemerintah non-kementerian yang mengurus urusan pemerintahan yang tidak diserahkan kepada daerah otonom dalam wilayah tertentu dalam rangka dekonsentrasi;

c. Pasal 1 angka 13: Wilayah Administratif adalah wilayah kerja perangkat pemerintah pusat termasuk gubernur sebagai wakil pemerintah pusat untuk menyelenggarakan urusan pemerintahan yang menjadi kewenangan pemerintah pusat di daerah dan wilayah kerja gubernur dan bupati/walikota dalam melaksanakan urusan pemerintahan umum di daerah;

d. Pasal 4 ayat (1): Daerah provinsi selain berstatus sebagai daerah juga merupakan wilayah administratif yang menjadi wilayah kerja bagi gubernur 
sebagai wakil pemerintah pusat dan wilayah kerja bagi gubernur dalam menyelenggarakan urusan pemerintahan umum di wilayah Daerah provinsi;

e. Pasal 4 ayat (2): Daerah kabupaten/kota selain berstatus sebagai daerah juga merupakan wilayah administratif yang menjadi wilayah kerja bagi bupati/walikota dalam menyelenggarakan urusan pemerintahan umum di wilayah daerah kabupaten/kota;

f. Pasal 5 ayat (4): Penyelenggaraan Urusan Pemerintahan sebagaimana dimaksud pada ayat (2) di Daerah dilaksanakan berdasarkan asas desentralisasi, dekonsentrasi, dan tugas pembantuan;

g. Pasal 10 ayat (1): Urusan Pemerintahan Absolut sebagaimana dimaksud dalam Pasal 9 ayat (2) meliputi: politik luar negeri, pertahanan keamanan, yustisi, moneter dan fiskal nasional, dan agama;

h. Pasal 10 ayat (2): Dalam menyelenggarakan Urusan Pemerintahan Absolut sebagaimana dimaksud pada ayat (1), Pemerintah Pusat:

1) melaksanakan sendiri; atau

2) melimpahkan wewenang kepada instansi vertikal yang ada di daerah atau gubernur sebagai wakil pemerintah pusat berdasarkan asas dekonsentrasi;

i. Pasal 25 ayat (1): Urusan-urusan pemerintahan umum sebagaimana dimaksud dalam Pasal 9 ayat (5) meliputi:

1) pembinaan wawasan kebangsaan dan ketahanan nasional dalam rangka memantapkan pengamalan Pancasila, pelaksanaan Undang-Undang Dasar Negara Republik Indonesia Tahun 1945, pelestarian Bhinneka Tunggal Ika serta pemertahanan dan pemeliharaan keutuhan Negara Kesatuan Republik Indonesia;

2) pembinaan persatuan dan kesatuan bangsa;

3) pembinaan kerukunan antarsuku dan intrasuku, umat beragama, ras, dan golongan lainnya guna mewujudkan stabilitas keamanan lokal, regional, dan nasional;

4) penanganan konflik sosial sesuai ketentuan peraturan perundang undangan;

5) koordinasi pelaksanaan tugas antar instansi pemerintahan yang ada di wilayah daerah provinsi dan daerah kabupaten/kota untuk menyelesaikan permasalahan yang timbul dengan memperhatikan prinsip demokrasi, hak asasi manusia, pemerataan, keadilan, keistimewaan dan kekhususan, potensi serta keanekaragaman daerah sesuai dengan ketentuan peraturan perundang-undangan;

6) pengembangan kehidupan demokrasi berdasarkan Pancasila; dan

7) pelaksanaan semua urusan pemerintahan yang bukan merupakan kewenangan daerah dan tidak dilaksanakan oleh instansi vertikal. 
j. Pasal 25 ayat (2): Urusan Pemerintahan Umum sebagaimana dimaksud pada ayat (1) dilaksanakan oleh gubernur dan bupati/walikota di wilayah kerja masing-masing;

k. Pasal 25 ayat (3): Untuk melaksanakan Urusan Pemerintahan Umum sebagaimana dimaksud pada ayat (2), gubernur dan bupati/walikota dibantu oleh instansi vertikal;

I. Pasal 25 ayat (4): Dalam melaksanakan Urusan Pemerintahan Umum, gubernur bertanggung jawab kepada presiden melalui menteri, dan bupati/walikota bertanggung jawab kepada menteri melalui gubernur sebagai wakil pemerintah pusat;

m. Pasal 25 ayat (5): Gubernur dan bupati/walikota dalam melaksanakan Urusan Pemerintahan Umum dibiayai dari APBN;

n. Pasal 25 ayat (6): Bupati/walikota dalam melaksanakan Urusan Pemerintahan Umum sebagaimana dimaksud pada ayat (2) pada tingkat kecamatan melimpahkan pelaksanaannya kepada camat; dan

o. Pasal 25 ayat (7): Ketentuan lebih lanjut mengenai pelaksanaan Urusan Pemerintahan Umum sebagaimana dimaksud pada ayat (2) sampai dengan ayat (6) diatur dalam peraturan pemerintah.

Berdasarkan pengaturan dalam beberapa pasal tersebut, dapat disimpulkan bahwa gubernur sebagai pemerintah daerah provinsi dapat melaksanakan urusan pemerintahan wajib berdasarkan desentralisasi, urusan pemerintahan absolut (pemerintah pusat) berdasarkan dekonsentrasi, dan urusan pemerintahan umum (kewenangan presiden) ${ }^{33}$ berdasarkan dekonsentrasi. Namun, untuk daerah kabupaten dan kota dengan kepala daerah bupati dan walikota, dapat melaksanakan urusan pemerintahan wajib berdasarkan desentralisasi dan urusan pemerintahan umum berdasarkan dekonsentrasi.

Dilihat dari perincian urusan pemerintahan umum dalam Pasal 25 ayat (1) UU Pemda 2014 di atas, urusan-urusan yang didekonsentrasikan terkait dengan pembinaan kesatuan bangsa, Pancasila, kerukunan antar dan intra suku, koordinasi antar instansi, ketahanan, penanganan konflik, dan lain-lain yang bertujuan untuk mempererat persatuan dan kesatuan negara. Sangat beralasan jika penyelenggaraan dekonsentrasi hingga ke daerah kabupaten dan kota, karena halhal tersebut adalah urusan yang sangat penting bagi kehidupan berbangsa dan bernegara. Selain itu, urusan-urusan tersebut harus menjadi kewajiban bersama antara pusat dan daerah demi NKRI yang aman, tentram, dan utuh.

\footnotetext{
33 Pasal 9 ayat (5) UU Pemda 2014.
} 


\section{Penutup}

\section{Kesimpulan}

Pengaturan Pasal 1 ayat (9), Pasal 4 ayat (2), dan Pasal 25 ayat (1) UU Pemda 2014 mengenai dekonsentrasi penyelenggaraan urusan pemerintahan umum hingga kepada walikota dan/atau bupati adalah pengaturan yang konstitusional, meskipun dalam UUD 1945 khususnya Pasal 18, 18A, dan 18B yang diatur mengenai pemerintahan daerah, tidak terdapat pengaturan mengenai dekonsentrasi. Hal ini dikarenakan dekonsentrasi pada dasarnya merupakan suatu mekanisme yang sangat wajar dalam sistem pemerintahan daerah. Dekonsentrasi dalam penyelenggaraannya dapat disandingkan dengan desentralisasi, bahkan keberadaan dekonsentrasi melengkapi adanya desentralisasi serta tugas pembantuan. Khususnya di NKRI, yang memiliki wilayah yang luas, yang terdiri dari daerah-daerah yang memiliki keragaman dan ingin melakukan percepatan pembangunan hingga ke daerah, maka dekonsentrasi adalah salah satu mekanisme yang dapat digunakan untuk menyelenggarakan urusan Pemerintah Pusat di daerah, yang juga bertujuan untuk melakukan pengawasan, supervisi, dan mempererat NKRI.

Selain itu, pengaturan dekonsentrasi dalam UU Pemda 2014 ini janganlah diartikan sebagai pengaturan yang mengarah kepada re-sentralisasi. Karena pengaturan dekonsentrasi ini pada dasarnya tidak mengancam keberadaan desentralisasi, tetapi untuk melengkapi desentralisasi dalam lingkup NKRI. Apalagi jika melihat urusan-urusan pemerintahan umum yang diselenggarakan oleh daerah kabupaten dan kota berdasarkan dekonsentrasi yang diatur dalam UU Pemda 2014 ini adalah urusan-urusan yang berkaitan dengan persatuan dan kesatuan negara, tentunya hal ini adalah bukan hanya menjadi tanggung jawab pemerintah pusat, tetapi juga adalah kewajiban dan tanggung jawab dari pemerintah daerah sebagai bagian dari Negara Kesatuan Republik Indonesia.

\section{Saran}

Karena UU Pemda 2014 ini juga mengatribusikan kepada pemerintah untuk membentuk peraturan pemerintah mengenai dekonsentrasi dan tugas pembantuan serta peraturan pemerintah mengenai penyelenggaraan urusan pemerintahan umum, maka pemerintah harus segera membuat peraturan pemerintah ini agar peraturan mengenai dekonsentrasi dan tugas pembantuan serta penyelenggaraan urusan pemerintahan Umum ini dapat dilaksanakan secara terstruktur, terencana, sistematis dan efektif serta efisien berdasarkan Peraturan Pemerintah tersebut. 


\section{Daftar Pustaka}

\section{Buku}

Adnan Buyung Nasution, Arus Pemikiran Konstitusionalisme, Kata Hasta Pustaka, Jakarta, 2007.

Bagir Manan, Menyongsong Fajar Otonomi Daerah, Pusat Studi Hukum FH UII, Yogyakarta, 2001. , Perjalanan Historis Pasal 18 UUD 1945, UNISKA, Jakarta, 1993.

Jimly Asshiddiqie, Konstitusi \& Konstitusionalisme Indonesia, Konstitusi Press, Jakarta, 2005.

, Pokok-Pokok Hukum Tata Negara Indonesia Pasca Reformasi, PT. Bhuana Ilmu Populer, Jakarta, 2007.

Majelis Permusyawaratan Rakyat RI, Panduan Dalam Memasyarakatkan UUD Negara Republik Indonesia Tahun 1945, Sekretariat Jendral MPR RI, Jakarta, 2003.

Ni'matul Huda, Hukum Pemerintahan Daerah, Penerbit Nusa Media, Bandung, 2009.

\section{Dokumen Lain}

Bernard Bizet, "Deconcentration versus Decentralization of Administration in France", Canadian Journal of Regional Science, XXV: 3, Autumn, 2002.

Elizabeth Linda Yuliani, "Decentralization, Deconcentration and Devolution: What Do They Mean?", Interlaken Workshop on Decentralization, Interlaken, Switzerland, 27-30 April 2004.

Iskatrinah, "Dekonsentrasi Dalam Penyelenggaraan Otonomi Luas Berdasarkan Undang-Undang Dasar 1945", Disertasi Fakultas Hukum Universitas Padjadjaran, Bandung, 2015.

TIM PKP2A III LAN, "Kewenangan Dekonsentrasi Dalam Penyelenggaraan Otonomi Daerah dan Permasalahan Penyelenggaraannya di Daerah", Penelitian PKP2A III LAN Samarinda, 2007.

\section{Dokumen Hukum}

Undang - Undang Dasar 1945 Sebelum Amendemen.

Undang - Undang Dasar 1945 Pasca Amendemen.

Undang - Undang Nomor 32 Tahun 2004 tentang Pemerintahan Daerah. Undang - Undang Nomor 23 Tahun 2014 tentang Pemerintahan Daerah. Undang - Undang Nomor 1 Tahun 1945 tentang Pemerintahan Daerah. Undang - Undang Nomor 22 Tahun 1948 tentang Pemerintahan Daerah. Undang - Undang Nomor 1 Tahun 1957 tentang Pemerintahan Daerah. Undang - Undang Nomor 18 Tahun 1965 tentang Pemerintahan Daerah. Peraturan Presiden Nomor 6 Tahun 1959 